\title{
Empirical Analysis of Food Security Status of Farming Households in Benue State, Nigeria.
}

\author{
Ahungwa, G. T*; Umeh, J. C** and Muktar, B. G*. \\ *Department of Agricultural Economics and Extension, Federal University Dutse, P.M.B. 7156, Dutse-Nigeria. \\ ${ }^{* *}$ Department of Agricultural Economics, University of Agriculture, P.M.B. 2373, Makurdi-Nigeria.
}

\begin{abstract}
In the most recent times, no human right has been so frequently and spectacularly violated as the right to food. In the light of the global food crisis, this paper analyzed the food security status of farming households in Benue State, "the Food Basket" of Nigeria. The paper employed a stage-wise random sampling technique to obtain 180 households. Descriptive statistics were used to assess the socio-economic characteristics of the households and the Food Security Index was used to measure the household food security status. Using the FAO benchmark of 2500kcal per capita per day; households were profiled into food secure and food insecure where $36.67 \%$ were food secure while $63.33 \%$ were food insecure. The shortfall or surplus index $(P)$ indicated that, the food secure households exceeded the benchmark by $33.80 \%$ while the food insecure categories fell short by $29.60 \%$. The paper recommends that, government and all stakeholders should take advantage of existing structures such as the Fadama Development Project to improve the means of livelihood of the populace, thus improving their food security status; enhance nutritional education for effective home management and balance dietary intake rather than 'full the stomach syndrome' to achieve the Millennium Development Goal of reducing to half poverty and hunger incidence by the year 2015.
\end{abstract}

Key words: Food security Status, farming households, food security index.

\section{Introduction}

The issue of food security is of high importance to Nigeria vis-à-vis the fact that the country's average caloric and protein intake is only at the threshold of adequacy with increasing incidence of food insecurity. In the same vein, poverty incidence over the years increased sharply between 1980,1985, 1992, and 1996, with a slight decline in 2004. These figures were $28.1 \%$, translated to 18.24 million people, $46.3 \%$ ( 34.73 million), $42.70 \%$ (39.07million), $65.6 \%$ (67.11million) and 54.40\% (68.70million) respectively (NBS, 2005; Sanusi et $a l$, 2006). However, the decline in 2004 did not translate into the proportion in poverty as the nation's population is at an increasing rate.

As food situation in Nigeria worsened after the 1960s, government had introduced a number of agricultural development institutions and special programmes and projects to arrest the enormous challenges of food insecurity and poverty. These include: National Accelerated Food Production Progamme, NAFPP (1973); Agriculture Development Project, ADP (1975); Operation Feed the Nation, OFN (1976); National Seed Service, NSS(1977); Agricultural Credit Guarantee Scheme ACGS(1977); Rural Banking Scheme, RBS(1977); Green Revolution GR(1979); Directorate of Food, Road and Rural Infrastructure, DFRRI(1986); National Agriculture Land Development Authority, NALDA(1992), National Fadama Development Project, NFDP I ,II, and III(1992, 1999 and 2008 respectively);Nigeria Agricultural Cooperative and Rural Development Bank, NACRDB (2000); National Agricultural Development Fund, NADF(2002); National Special Programme on Food Security, NSPFS (2002); Commodity Marketing and Development Companies, CMDC (2003) and more recently, the Presidential Initiatives on selected crops (2004-2005), 7 Points Agenda with emphasis on Food Security (2009) and the Agricultural Transformation Agenda of the present administration. However, according to Idachaba (2004), empirical records these initiatives are not impressive to bring about the transformation of the sector. The paradox is that, there is yet threat of hunger and poverty.

In Benue State, the situation is not different. The state prides itself as the food basket of Nigeria. However recent events seen to threaten this claim as about $78.3 \%$ of her populace still live below the poverty line with notable incidence of hunger and food insecurity (ACTIVISTA, 2009). This paper is modeled along the following objectives; to assess the socio-economic attributes of farming households as they influence food security status of the State and to generate food security indices for the farming households in Benue State.

Food Security in Nigeria: The World Food Summits, 1974 and 1996 and the ICN of 1992 adopted and endorsed the resolutions that "all governments should accept that within a decade, no child will go to bed hungry, that no family will fear for its next day's bread and that no human being's future and capabilities will be stunted by malnutrition (FAO, 1996). Nigeria with other 48 countries entered this treaty and made a commitment to reduce the number of chronically undernourished people, globally, and nationally to half by the 
year 2015 (FAO, 2002). However, less than three years to the target year, available statistics still cast doubt whether this goal could be achieved by 2015.

In the view of Babatunde et al. (2007), among the developmental problems facing Nigeria, food security problem ranks topmost. Available statistics show that the Nigeria food security picture is pathetic as more than 70 percent of the populace live in households too poor to have regular access to the food that they need for healthy and productive living (Aletor, 1999) ascribing Nigeria with highest incidence of food insecurity in Africa (FAO, 2005).

In the analysis of Iremiren (1992), "Jesus taught us to pray for our daily bread among other requests in the family prayers. For many years now, the price of the symbolic bread has gone beyond the reach of most Nigerians and it has disappeared from the breakfast menu. For few that still eat bread, it is no more daily". Fasting in Nigeria has become the order of the day, not as a means of drawing nearer to God alone, but as a means of sustaining hope for another day's meal (Tewe, 1997). This statement is underpinned by the now universal 001; 101; 010; 110 etc menu formulae adopted not by students alone, but workers and indeed many households, whereby meals are skipped out of sheer necessity to ensure the availability of another day's maintenance ration (Aletor, 1999).

\section{Methodology}

The Study Area: Benue State (the Food Basket of the Nation) is located in the Middle Belt region of Nigeria, between Longitude $6^{\circ} 31^{\prime} \mathrm{E}$ and $10^{\circ} \mathrm{E}$ and between Latitudes $6^{\circ} 30^{\prime} \mathrm{N}$ and $8^{\circ} 10^{\prime} \mathrm{N}$ (BNARDA, 2005).

Benue State has a total land mass of about $33,955 \mathrm{Km}^{2}$ with 23 Local Government Areas, politically and agriculturally divided into three zones; Zone A, B and C with a total population of 4,219,244 people and 413,159 households (BNARDA, 2005; NPC, 2006).

Sampling Techniques: The population for the study comprised the farm-families (households) of Benue State drawn from the three agricultural zones. The selection of the sample involved a three stage-wise simple random sampling approach. In the first stage, a random selection of three (3) Local Government Areas each from the three agricultural zones of the State was made.

The second stage involved a random selection of 10 villages from each of the nine selected Local Government Areas giving a total of 90 villages. In the last stage, 180 farming households were selected from the earlier 90 villages sampled for the study, that is, two household per village using the concept of 20-30 households per village.

Data Collection Method and Instruments: In this paper, a 7-day recall method was used and the estimated quantities of every food item consumed by the household in the 7-day period calculated. The quantities were converted to gram and the caloric content estimated by using the nutrient composition table of commonly eaten foods in Nigeria.

The primary data were collected with a well-structured questionnaire, designed to capture general information about household characteristics, food consumption, income and expenditure. The secondary data were gathered from the State Ministry of Agriculture, Benue State Agricultural and Rural Development Authority, (BNARDA), Bureau of Statistics, published and unpublished Theses and the internet.

Methods of Data Analysis: This paper measured food security by direct surveys of dietary intake (in comparison with appropriate adequacy norms). The paper used Food Security Index and other statistical tools to assess households' food security (HFS). To measure the households' food security, a food security index was constructed. This involved two steps; defining a minimum level of nutrition necessary to maintain a healthy living, the food security line, below which households is classified as food insecure and aggregation, derived from food security statistics (Agboola et al., 2004, Babatunde et al., 2007). Caloric adequacy was estimated by dividing calorie supplied for the household by the family size adjusted for adult equivalent using the consumption factor for age-sex categories (Runge-Metzger and Diehl, 1993). The frequencies, mean, standard deviation and other food security indices were determined using the Statistical Package for the Social Sciences (SPSS) Version 14.0.

\section{Model Specification \\ Food Security Index $(Z)$}

The food security index is expressed empirically as;

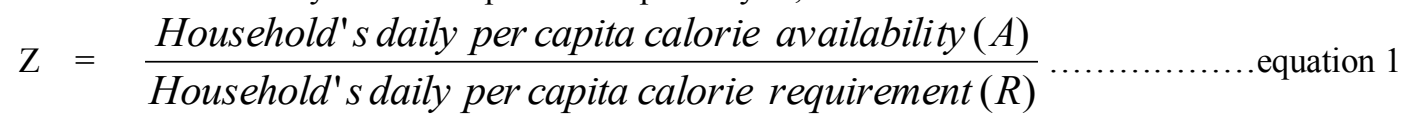


For this paper, the daily per capita calorie availability and requirement is used and a household is defined as a group of people living together and eating from the same pot and the lower limit of the FAO recommended daily caloric intake for an adult aged man (30-60 years) of 2500 kilocalories which is slightly below the FAO 2730 kcal target for developing countries by 2010 (FAO, 1996) is used as a threshold for food security status. Based on $\mathrm{Z}$, several food security measures were calculated; the shortfall/surplus index, $\mathrm{P}$, as

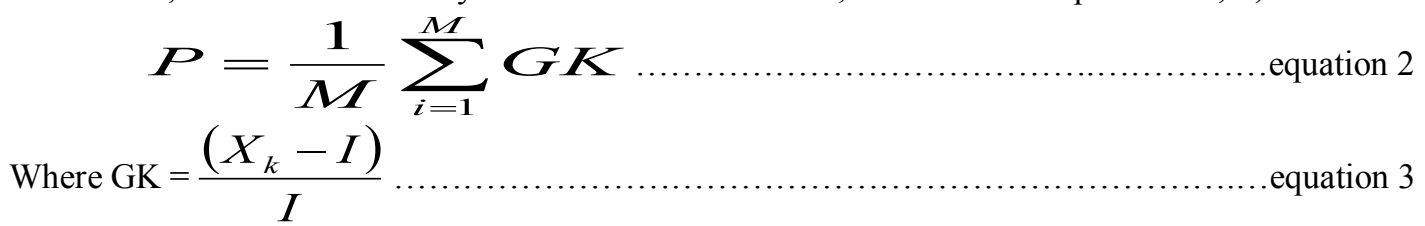

This is the deficiency or surplus faced by household $\mathrm{j}$.
$\mathrm{P}=\quad$ Shortfall or surplus index
$\mathrm{X}_{\mathrm{k}}=\quad$ Average daily caloric available to the $\mathrm{j}^{\text {th }}$ household
$\mathrm{M}=\quad$ the number of households that are food secure (surplus index) or food insecure (short fall index)
$I=\quad$ the food security line $(2500 \mathrm{kcal})$.

The Head count ratio $(\mathrm{H})$ is given as

$\mathrm{H}=\mathrm{M} / \mathrm{N}$ equation 4

Where

$\mathrm{M}=\quad$ the number of food secure or insecure members of the sample population

$\mathrm{N}=\quad$ total population under study

\section{Results and Discussion}

Socio-economic Characteristics of the Farming Households: The result in Table 1 indicated that 93.94 percent in the food secure category were male and 6.06\% were female. Among the food insecure households, $71.93 \%$ are male and $28.07 \%$ females indicating male dominance. However, the male dominancy in the study area does not translate into a food secure region because of other factors such as the low land holdings and high family size that characterized the study area.

The age distribution of the food secure households showed $42.42 \%$ were within the age range of 40 and 49 years. Among the food insecure households, 31.58\% represents those within the ages of 50-59 years. This analysis showed that there could be a direct relationship with age and food security. The incidence of food insecurity weighed more on the household heads above 50 years. This may be as a result of the fact that the ages less than 50 years are more energetic and agile to do farm work, seek off-farm income generating activities to improve the welfare and food security of their households. (Insert Table 1 here).

In both the food secure and food insecure households, $89.39 \%$ and $66.67 \%$ were married. The farm size holding among the food secure group revealed that, 50\% had 2.1-4.0 hectares of land. On the contrary, 54.39\% of the food insecure households had 0.5-2ha. In an agrarian economy, the land as a unit for agricultural production provides the needed fulcrum upon which a sustainable development would blossom (Okuneye, 2007). However, half (50.00\%) of the households had 2.1-4ha of land, 37.88\% had 0.5-2ha while $12.12 \%$ had more than tha even among the food secure group. This result agrees strongly with the report of Babatunde et al., (2007) who stated that the typical land holding per households in the North central region of Nigeria is in the range of 0.1 and 2.5 hectares, thus predisposing the region to food insecurity. The child dependency ratio among the food secure households showed that 53.03\% had 2 and 3 children. Among the food insecure category, $50.88 \%$ had $0-1$ child. In both food secure and insecure group, the child dependency ratio decreases food security status of the households. This result agreed with the findings of Omonona and Agoi, (2007) that food security declines with increase dependency ratio especially without corresponding increase in income.

The annual income of $\$ 60,000-89,000$ was highest among the food secure group, $42.42 \%$. Among the food insecure group, 35.96\% earned between N30, 000-59,000. The largest group of the hungry comprises the members of households with low and variable incomes, limited assets, few marketable skills and few powerful advocates to act on their behalf (FAO, 1996). This result suggest that household income has a direct impact on food security status as households with relatively high income strive better than those with less income, agreeing with the findings of Agboola et al.,(2004) and Babatunde et al.,(2007).

The expenditure pattern for the food secure households showed that expenditure was highest, $34.85 \%$ among those that expended N41000-50000, among the food insecure, $41.23 \%$ represents the highest expenditure. This expenditure pattern when expressed on a monthly basis failed short of the cost of even $2250 \mathrm{kcal}$ estimated by Agboola et al., (2004) in his study on factors influencing food insecurity among rural households in Nigeria. 
Food Security Indices of the Households in Benue State: Based on the FAO recommended daily calorie intake of $2500 \mathrm{kcal} / \mathrm{adult}$ equivalent/day, it showed that $66(36.67 \%)$ households were food secure and $114(63.33 \%)$ was food-insecure (Table 2). The daily per capital caloric availability also showed that the food secure household exceeded the $2500 \mathrm{kcal}$ intake by $500.62 \mathrm{kcal}$ while the food insecure households fell short by $264.12 \mathrm{kcal}$ from the recommended caloric intake per person. The extent of deviation, the shortfall index or surplus index (p) showed that the food secure households exceeded the $2500 \mathrm{kcal}$ intake by $33.8 \%$ while the food insecure households failed short of requirement by $29.6 \%$.

The result also showed that the quantity of own production for the study area was 19.560 metric tonnes per household, yet, the households were food insecure agreeing with the views of Omonona and Agoi (2007) that the food security problem in Nigeria is not that of food production as there is enough domestic production, but a question of storage, marketing and distribution arrangement as well as unequal food access by members of the society. (Insert Table 2 here).

\section{Conclusion:}

This paper presents an empirical analysis of food security status among farming households in Benue State, Nigeria. The food security indicators for the state showed that $63.33 \%$ were food insecure, subsisting on less than $2500 \mathrm{kcal}$ per day, while $36.67 \%$ were food secure. The household daily per capita calorie availability for the food secure households was $3431.93 \mathrm{kcal}$, exceeding the minimum requirement of $2500 \mathrm{kcal}$ by $33.8 \%$ while the daily per capita calorie available for the food insecure group was $1719.42 \mathrm{kcal}$, fallen short of the minimum requirement by $29.6 \%$. The head count ratio showed that $36.7 \%$ of the individual members of the households were food secure and $63.3 \%$ were food insecure. The study concludes that, in spites of the tremendous efforts made in the agricultural at the national and state levels in the areas of policy intervention, the resultant effects are yet to be felt and the state, The Food Basket State, remains generally food insecure. The study thus encourages government and farmers to take advantage of programmes such as the National Fadama Development Project and the Special Programme for Food Security, which are targeted toward expanding the income frontiers and improving the livelihood of the farmers. In addition, the nation's Agricultural Transformation Agenda as a policy instrument should embrace nutritional education for effective home management and balance dietary intake rather than 'full the stomach syndrome' to achieve the Millennium Development Goal of reducing to half poverty and hunger incidence by the year 2015.

\section{References}

[1]. ACTIVISTA (2009). "Hunger in the Food Basket". Fighting against hunger in Nigeria, the Benue experience. Internet material, www.ourbenueourfuture.org, 12/07/2009.

[2]. Agboola, P.O., A.E. Ikpi and P.M. Kormawa (2004) "Factors Influencing Food Insecurity among Rural Farming Households in Africa: Results of Analysis From Nigeria”. Internet Discussion Paper, November, 2004. http/www.pjbs.org/pjnonline/ab577.

[3]. Aletor, V.A (1999). Inaugural Lecture Series 15, “Anti-nutritional Factors as Nature's Paradox in Food and Nutrition Securities". Federal University of Technology, Akure, $12^{\text {th }}$ August, 1999. Pp 1-88.

[4]. Babatunde, R.O Omotesho and O.S Sholotan (2007). Socio-Economic Characteristics and Food Security Status of Farming Households in Kwara State, North-Central Nigeria. Pakistan Journal of Nutrition 6(1): 49-59.

[5]. BNARDA (2005). Implementation Completion Report on National Special Programme for Food Security (NSPFS), Benue State, Nigeria. Pp 1-23.

[6]. Clay, E.J (2002). Food Security: 'Concepts and Measurement', Paper for FAO Expert Consultation on Trade and Food Security: Conceptualizing the Linkages, Rome, 11-12 July, 2002.

[7]. FAO (1983): World Food Security: Selected Themes and Issues. Economic and Social Development Paper 53, Rome. http/www.fao.org/worldfoodsummit.

[8]. FAO (1996). Food and Agriculture Organization. World Food Summit, November 13-17, 1996, Rome, Italy. Technical Background Documents, 6-13, Vol II. Pp1-47.

[9]. FAO (2002). The State of Food Insecurity in the World, 2002, Rome. Pp4-10

[10]. FAO (2005). Food and Agriculture Organization, the State of Food Insecurity in the World, 2005, Rome, Italy. P2.

[11]. Gross, R., W. Schultink and A.A Kielmann (1999). Community Nutrition; Definition and approaches. In: Encyclopedia of Human Nutrition. Sadler, M; Strain,J.J and Caballo, B. (Eds). Academic press Ltd, London, 433-441.

[12]. Idabacha, F.S (2004). Food Security in Nigeria: Challenges under Democratic Dispensation. Paper Presented at the $9^{\text {th }}$ ARMTI Annual Lecture, Illorin, $24^{\text {th }}$ March, 2004.

[13]. Iremiren, G.O (1992). Our Bread is no Daily, Inaugural Lecture Delivered at the Federal University of Technology, Akure, Nigeria, April 17, 1992.

[14]. NBS (2005). Poverty Profile for Nigeria. National Bureau of Statistics. Pp 1-98.

[15]. NPC (2006). National Population Census facts Sheet, issued $31^{\text {st }}$ April, 2007. B82.

[16]. Okuneye,S.A (2002). Raising cost of food prices and food insecurity in Nigeria and its implication on poverty reduction .CBN Economic and Financial review, Volume 39, No.4 pp1-15.

[17]. Omonona, B.T and G.A. Agoi (2007). An Analysis of Food Security Situation among Nigeria Households: Evidence from Lagos State, Nigeria. Journal of Central European Agriculture, Vol 8, No.3 Pp 397-406.

[18]. Runge-Metzger .A. and L. Diehl (1993) Farm household system in Northern Ghana: A case study in farming systems - oriented research for the Development of improved crop production system. Nyankpata Agricultural Research Report No.9, 1993. Nyankpata, Ghana.

[19]. Sanusi R.A. C.A Badejo and B.O Yusuf (2006). Measuring Household Food Insecurity in Selected Local Government Areas of Lagos and Ibadan Nigeria. Pakistan Journal of Nutrition, 5:62-67. 
Empirical Analysis of Food Security Status of Farming Households in Benue State, Nigeria.

[20]. Schaffer, J (2002) 'Food Security and Safety', Economic Perspective. An Electronic Journal of the US Department of State 7 (2):2.

[21]. Stefan, D and K Pramila (1998). Changes in Poverty in Rural Ethiopia 1989-1995, Measurement, Robustness Tests and Decomposition, Center for the Study of Africa Economics, Working Paper series.

[22]. Tewe, O.O (1997) "Sustainability and Development: Paradigms from Nigeria's Livestock Industry", Inaugural Lecture Delivered at the University of Ibadan, Ibadan, October 9, 1997.pp 1-84.

[23]. World Bank (1986). Nigeria: Poverty in the midst of plenty. The challenge of Growth with inclusion. Report No. 14733-UNI, Washington, DC. Pp346.

[24]. World Bank (2001). World Bank Development Report 2000/2001; Attacking Poverty, New York, Oxoford University Press.249pp.

TABLE 1. Descriptive Statistics of the Socio-economic Attributes of the Farming Households in Benue State.

\begin{tabular}{|c|c|c|c|c|}
\hline \multirow[t]{2}{*}{ Index } & \multicolumn{2}{|c|}{ Food Secure Households } & \multicolumn{2}{|c|}{ Food Insecure Households } \\
\hline & Frequency & Percentage & Frequency & Percentage \\
\hline \multicolumn{5}{|l|}{ 1. Sex } \\
\hline Male & 62 & 93.94 & 82 & 71.93 \\
\hline Female & 4 & 6.06 & 32 & 28.07 \\
\hline Total & 66 & 100.00 & 114 & 100.00 \\
\hline \multicolumn{5}{|l|}{ 2. Age (Years) } \\
\hline$\leq 29$ & 3 & 4.55 & 4 & 3.51 \\
\hline $30-39$ & 19 & 28.78 & 18 & 15.79 \\
\hline $40-49$ & 28 & 2.42 & 30 & 26.32 \\
\hline $50-59$ & 14 & 21.21 & 36 & 31.58 \\
\hline$\geq 60$ & 2 & 3.03 & 26 & 22.81 \\
\hline Total & 66 & 100.00 & 114 & 100.00 \\
\hline \multicolumn{5}{|l|}{ 3. Marital Status } \\
\hline Single & 3 & 4.55 & 1 & 0.88 \\
\hline Married & 59 & 89.39 & 76 & 66.67 \\
\hline Divorced & 1 & 1.52 & 6 & 5.26 \\
\hline Widow/Widower & 3 & 4.55 & 31 & 27.19 \\
\hline $\begin{array}{l}\text { Total } \\
\text { 4. Farm Size (ha) }\end{array}$ & 66 & 100.00 & 114 & 100.00 \\
\hline $0.5-2.0$ & 25 & 37.88 & 62 & 54.39 \\
\hline $2.1-4.0$ & 33 & 50.00 & 49 & 42.98 \\
\hline$>4.0$ & 8 & 12.12 & 3 & 2.63 \\
\hline Total & 66 & 100.00 & 114 & 100.00 \\
\hline \multicolumn{5}{|c|}{ 5.Child Dependency Ratio } \\
\hline $0-1$ & 30 & 45.45 & 58 & 50.88 \\
\hline $2-3$ & 35 & 53.03 & 45 & 39.47 \\
\hline$\geq 4$ & 1 & 1.52 & 11 & 9.65 \\
\hline Total & 66 & 100.00 & 114 & 100.00 \\
\hline \multicolumn{5}{|c|}{ 6. Household Size (No.) } \\
\hline $1-3$ & 2 & 3.03 & 5 & 4.39 \\
\hline $4-6$ & 29 & 43.94 & 12 & 10.3 \\
\hline 7 and above & 35 & 53.04 & 97 & 85.09 \\
\hline Total & 66 & 100.00 & 114 & 100.00 \\
\hline \multicolumn{5}{|c|}{ 7.Educational Status (Years) } \\
\hline Informal Education & 18 & 27.27 & 72 & 63.16 \\
\hline Primar & 19 & 28.79 & 35 & 30.70 \\
\hline Secondary & 20 & 30.30 & 7 & 6.14 \\
\hline Tertiary & 9 & 13.64 & 0 & 0 \\
\hline Total & 66 & 100.00 & 114 & 100.00 \\
\hline \multicolumn{5}{|c|}{ 8.Income (N'000)/annum } \\
\hline$\leq 29$ & 0 & 0 & 36 & 31.58 \\
\hline $30-59$ & 19 & 28.79 & 41 & 35.96 \\
\hline $60-89$ & 28 & 42.42 & 27 & 23.68 \\
\hline $90-119$ & 8 & 12.12 & 10 & 8.77 \\
\hline 120 and above & 11 & 16.67 & 0 & 0 \\
\hline Total & 66 & 00.00 & 114 & 100.00 \\
\hline \multicolumn{5}{|c|}{ 9.Expenditure (N’000)/annum } \\
\hline$\leq 20$ & 0 & 0 & 19 & 16.67 \\
\hline $21-30$ & 7 & 10.61 & 38 & 33.33 \\
\hline $31-40$ & 19 & 28.79 & 47 & 41.23 \\
\hline $41-50$ & 3 & 34.85 & 9 & 7.89 \\
\hline 51 and above & 17 & 25.76 & 1 & 0.88 \\
\hline Total & 66 & 100.00 & 114 & 100.00 \\
\hline \multicolumn{5}{|c|}{ 10. Quantity of own production $(000 \mathrm{~kg})$} \\
\hline$\leq 50$ & 0 & 0 & 14 & 1.28 \\
\hline $51-80$ & 4 & 6.06 & 64 & 56.14 \\
\hline $81-110$ & 22 & 33.33 & 34 & 29.82 \\
\hline $111-130$ & 18 & 27.27 & 2 & 1.75 \\
\hline 131 and above & 22 & 33.34 & 0 & 0 \\
\hline Total & 66 & 100.00 & 11 & 100.00 \\
\hline
\end{tabular}

Source: Field Survey, 2010 
Empirical Analysis of Food Security Status of Farming Households in Benue State, Nigeria.

Table 2. Summary of Food Security Statistics of Farming Households in Benue State

\section{VARIABLES HOUSEHOLDS}

\begin{tabular}{|c|c|c|c|}
\hline Food Security Indices & Food Secure & Food-insecure & Total/Mean \\
\hline \multicolumn{4}{|l|}{ Recommended/Capita Calorie Intake(I),2500 Kcal } \\
\hline No. of Households & $66(36.67 \%)$ & $114(63.33 \%)$ & $180(100 \%)$ \\
\hline \multicolumn{4}{|l|}{ Sex of Household Heads } \\
\hline Male & 62 & 82 & 144 \\
\hline Female & 4 & 32 & 36 \\
\hline Age of Household Head & 43.64 & 49.96 & 46.8 \\
\hline Household Size (adjusted to adult equivalent) & 6.58 & 11.42 & 8.995 \\
\hline Household own production (grain equiv),'000 kg & 12.026 & 7.533 & 19.559 \\
\hline Household Farm Size (ha) & 3.01 & 2.44 & 2.725 \\
\hline Household Annual Income (N) & 83955 & 52553 & 68254 \\
\hline Household daily calorie availability (kcal) & 22623.62 & 15039.395 & 18831.51 \\
\hline Household daily calorie requirement (kcal) & 16719.697 & 22013.16 & 19366.55 \\
\hline Household daily/capita calorie availability (kcal) & 3431.925 & 1719.42 & 2575.67 \\
\hline Household daily/capita calorie requirement (kcal) & 2540.987 & 1925.677 & 2233.33 \\
\hline \multicolumn{4}{|l|}{ Food Security Index (Z) } \\
\hline Mean Calorie & 1.353 & 0.683 & 1.018 \\
\hline Standard Deviation & 0.178 & 0.096 & 0.137 \\
\hline Household daily/capita calorie availability (kcal) & 3431.93 & 1719.42 & 2575.67 \\
\hline Standard Deviation & 500.62 & 264.12 & 382.37 \\
\hline Shortfall/Surplus Index (P) & 0.338 & 0.296 & 0.317 \\
\hline Standard Deviation & 0.169 & 0.096 & 0.1325 \\
\hline Head Count Ratio, $(\mathrm{H}=\mathrm{M} / \mathrm{N})$ & 0.367 & 0.633 & 1 \\
\hline
\end{tabular}

Source: Field Survey, 2010 